\title{
Control of Superficial Scald of Apples by Low-oxygen Atmospheres
}

\author{
Zhenyong Wang and David R. Dilley ${ }^{1}$ \\ Department of Horticulture, Michigan State University, East Lansing, MI 48824-1325
}

\section{OVERVIEW OF THE PROBLEM}

Superficial scald is a pervasive physiological disorder of apples and pears (Pyrus malus L.) (Ingle and D'Souza, 1989), causing browning of the skin during or after low-temperature storage in air or after controlled-atmosphere (CA) storage, destroying the appearance and fresh-market value of the fruits. The affected cells of the hypodermis die and dehydrate (Bain, 1956; Bain and Mercer, 1963). Affected fruits may be processed as juice or sauce or sliced for bakery products, but product yield is reduced by trimming and costs are increased because of higher labor input. The physiology and control of scald have been reviewed periodically (Blanpied, 1990; Emongor et al., 1994; Ingle and D'Souza, 1989; Meigh, 1970; Smock, 1961), but not recently, and much has been learned from recent, expanded efforts in scald research. This review focuses on the etiology of scald in relation to low-oxygen stress regimens that control scald and the role of volatiles which have been implicated in this physiological disorder.

Apples and pears are major U.S. horticultural crops and are consumed as fresh fruits, minimally processed, sliced fruits, and, after processing, as canned or frozen products, sauce, and bakery and juice items. The domestic and export markets for these fresh fruits are large. Large crops require that more than half of the fruits grown be stored for up to a year in refrigerated air or CA storage to allow orderly marketing for fresh and processed fruit. The scald disorder is induced by storage at the low temperatures required to delay ripening. Most cultivars of apples and pears are susceptible to scald (Ingle and D'Souza, 1989). Scald has the potential to destroy the market value and utility of millions of tons of apples and pears annually unless the fruits are treated with a postharvest drench with diphenylamine (DPA) or ethoxyquin (6-ethoxy-1,2-dihydro-2,2,4trimethylquinoline). The possible loss of DPA for controlling apple scald has prompted renewed interest among researchers worldwide in developing alternative strategies to control scald.

\footnotetext{
Received for publication 24Feb. 1999. Accepted for publication 22 Apr. 1999. The cost of publishing this paper was defrayed in part by the payment of page charges. Under postal regulations, this paper therefore must be hereby marked advertisement solely to indicate this fact.

${ }^{1}$ Phone: 517-355-3286; fax: 517-381-0890; e-mail: dilley@pilot.msu.edu
}

\section{FACTORS RELATED TO THE SUSCEPTIBILITY OF APPLES TO SCALD}

Much is known about the factors that predispose apples to scald, storage conditions that favor or reduce scald, and postharvest treatments that may control it, and some insight has been gained about physical, physiological, and biochemical mechanisms that may help explain the nature and control of the disorder. Here we summarize salient information gained from a vast body of scald-related research spanning the past 60 years about factors and treatments that reduce or control scald, and discuss the characteristics and manifestations of scald and the factors that have been implicated in its development and control.

\section{Characteristics and manifestations of scald}

- It affects most, but not all cultivars of apples, which suggests a genetic basis for the disorder.

- It is a dysfunction of the pigment-containing cells of the hypodermis, especially, but not limited to, the non-red portion of the fruit surface.

- It is less prevalent with fruits harvested after exposure to cool temperatures late in the growing season.

- It becomes more prevalent as the fruits senescence or age during storage and upon subsequent warming.

- It is a manifestation of membrane-based chilling injury.

- It is caused by accumulation of a volatile by-product of metabolism in the affected cells. - It may be a consequence of oxidative metabolism involving reduced species of $\mathrm{O}_{2}$, e.g., active $\mathrm{O}_{2}$ species (AOS) such as $\mathrm{O}_{2}^{-}, \mathrm{H}_{2} \mathrm{O}_{2}$, and free radicals derived from them, such as the hydroxyl radical $(\cdot \mathrm{OH})$, peroxyl radical $(\cdot \mathrm{OOH})$, and perhaps singlet $\left({ }^{1} \mathrm{O}_{2}\right)$.

- It is a metabolic dysfunction probably caused by oxidation of $\alpha$-farnesene to 6-methyl-5-hepten-2-one (MHO) and its subsequent metabolism via free-radical intermediates.

- Cell death may be caused by the oxidation of essential amino acid functional groups of enzymes and of membrane lipids to carbonyl derivatives, preventing them from functioning, or targeting the proteins for proteolysis.

Factors, postharvest treatments, and storage regimens that reduce scald incidence:

- An ample level of naturally occurring antioxidants, such as ascorbic acid, carotenoids, $\alpha$-tocopherol, and glutathione, which act to scavenge free-radicals.

- Exogenously applied antioxidants such as DPA, 6-ethoxy 1,2-dihydro 2,2,4- trimethyl quinoline (ethoxyquin), ascorbate-6-palmitate, butylated hydroxy toluene (BHT), butylated hydroxyanisole (BHA), and squalene, which scavenge free-radicals if applied shortly after harvest.

- Hypobaric ventilation during the first month of storage of fruits stored subsequently in air or CA, respectively.

- CA storage at ultra-low $\mathrm{O}_{2}$ levels, e.g., $0.7 \% \mathrm{O}_{2}$.

- CA storage at $1.5 \% \mathrm{O}_{2}$ with ventilation to scrub carbon dioxide.

- Ethanol vapor treatment of fruits before CA storage.

- Initial low-oxygen stress (ILOS) at $0.5 \%$ $\mathrm{O}_{2}$ for 2 weeks before CA storage at $1.5 \% \mathrm{O}_{2}$.

\section{Cultivars}

Some cultivars of apple, e.g., 'Law Rome', 'Granny Smith', 'Delicious', 'McIntosh', and 'Cortland', are particularly susceptible to scald, while others, e.g., 'Empire' and 'Golden Delicious', show some natural resistance (Emongor et al., 1994; Ingle and D'Souza, 1989). The genetic basis for differing susceptibilities to scald among cultivars is not known. Studies under way at Cornell Univ. by Dr. Chris Watkins may provide this needed insight.

\section{Preharvest factors}

Environment during the growing season influences scald susceptibility, as does mineral nutrition (Emongor et al., 1994; Fidler, 1957). Apples with low calcium levels often develop more scald than those with high levels (Bramlage et al., 1974). Heavy application of nitrogenous fertilizers increases scald susceptibility in 'McIntosh' apples (Weeks et al., 1958). Apples grown under warm and dry environmental conditions are generally more prone to scald than when grown in cooler climates. This may be related to the nature and amount of the cuticular wax components developed on the fruit and during storage (Emongor et al., 1994).

\section{Maturity}

Scald is generally more problematic with fruits of all cultivars when they are harvested while immature. Susceptibility to scald decreases with fruit maturity when fruits are sampled from the same trees in the same season (Anet, 1972b; Christopher, 1941; Ingle 
and D'Souza, 1989). Immature fruits are very susceptible to scald ( Huelin and Coggiola, 1968), but apple growers have been compelled to harvest apples relatively immature to extend the CA storage season beyond 6 months. Early harvesting of some cultivars, e.g., 'Granny Smith', is encouraged to ensure high chlorophyll levels needed for successful marketing and this exacerbates its scald problem. But even 'Granny Smith' becomes less prone to scald when allowed to achieve full maturity before harvest. Delayed harvest increases the concentrations of $\alpha$-tocopherol and carotenoids, but not ascorbic acid, and greatly reduces scald development (Barden and Bramlage, 1994c). Ethephon (2-chloroethylphosphonic acid), an ethylene-generating chemical, hastens ripening and reduces scald (Couey and Williams, 1973; Greene et al., 1977; Hammett, 1976; Lurie et al., 1989b; Windus and Shutak, 1977). Early initiation of ripening by application of ethephon 3 to 5 weeks before harvest reduced superficial scald while increasing the content of lipid-soluble antioxidants in the fruit peel after 8 months in storage (Curry, 1994).

\section{Prediction of superficial scald}

Some success has been achieved in predicting scald susceptibility of 'Cortland' and 'Delicious' apples in the northeastern United States (Barden and Bramlage, 1994a), based upon the accumulation of days or hours at temperatures below $10^{\circ} \mathrm{C}$ during the late maturation stage of fruit development. For other regions and cultivars this has given promising but mixed results (Watkins and Bramlage, 1994).

\section{Chilling injury}

Superficial scald is considered to be a chilling injury-related disorder (Watkins et al., 1995). In support of this premise, Melville and Hardisty (1953) found good control of scald in 'Granny Smith' apples by storing them at $\approx 5$ ${ }^{\circ} \mathrm{C}$ in air for several weeks followed by storage at $0{ }^{\circ} \mathrm{C}$; apple scald did not occur on fruits stored above $10^{\circ} \mathrm{C}$. However, a disorder similar to scald can be induced at $20^{\circ} \mathrm{C}$ by anaerobiosis followed by returning the fruits to air; it, too, was prevented by DPA (Dilley et al., 1963). Bauchot et al. (1999) have confirmed that anoxia can induce this scald-like disorder. Moreover, their studies show that as harvest is delayed, fruits are less susceptible to anoxic treatment; naturally occurring scald exhibits the same relationship with maturity (Huelin and Coggiola, 1968). Transferring tissues from anaerobic to aerobic atmospheres may promote the production of active $\mathrm{O}_{2}$ species (Crawford and Braendle, 1996), and this may explain anaerobic induction of scald (Bauchot et al., 1999). Storing fruits in air at 0 to $5^{\circ} \mathrm{C}$ increases their tendency to scald, although actual symptom development may appear many months later, as demonstrated by studies on the timing of application of a scald inhibitor (Watkins et al., 1995). To be effective in controlling scald, DPA must be applied shortly after harvest (Shutak and Christopher, 1960); it is ineffectual once the fruits have been in air storage for more than 3 to 4 weeks. This suggests that low-temperature storage in air potentiates scald development, and is consistent with scald being a manifestation of chilling injury. Intermittent warming treatments are sometimes effective in preventing scald; such treatments commonly reduce chilling injury in other fruits (Lurie, 1998).

Chilling injury is clearly associated with perturbation of membrane functions. Ethanol vapor treatment attenuates scald (Scott et al., 1995a) and also reduces chilling-induced injury of excised cucumber (Cucumis sativus L.) cotyledons, apparently by inducing stomatal closure (Saltveit, 1994). Other primary alcohols have a similar effect and their efficacy is related to their lipid solubilities; this was also found for retardation of senescence in oat (Avena sativus L.) leaves (Satler and Thimann, 1980). Primary alcohols affect many metabolic processes in a similar manner, as noted by Saltveit (1994); examples include ATPase activity, electron transport, membrane permeability, and photophosphorylation. Thus, alcohols may exert their effects at a fundamental level involving the plasmalemma. Primary alcohols are excellent nucleophilic acceptors for the phosphatidyl moiety of all phospholipids (Heller, 1978). Phospholipase D (PLD), an ubiquitous enzyme requiring $\mathrm{Ca}^{2+}$, catalyzes a transphosphatidylation reaction in which the head group of the phospholipid is removed and a phosphatidyl alcohol is formed; with water as the acceptor, phosphatidic acid is formed. Alcohol utilization is a highly conserved feature of PLD (Ella et al., 1997). This reaction can occur in the plasmalemma in vivo. Inhibition of the normal reaction of PLD in forming phosphatidic acid by alcohols can have profound effects on plant processes by affecting a wide range of signal transduction systems (Ritchie and Gilroy, 1998). Ethanol vapor treatment inhibits $\alpha$-farnesene production and reduces scald (Grahramani and Scott, 1998a; Wang, 1998). Farnesol may also serve as an alcohol acceptor for phospholipase D, since it is a primary alcohol. Farnesol is not a precursor for $\alpha$-farnesene (Rupasinghe et al., 1998) in apple tissue, but is produced from farnesyl pyrophosphate at a 100 -fold greater rate than is $\alpha$-farnesene. Thus, sequestering $\alpha$ farnesol as a phosphatidyl alcohol by the action of PLD may effectively prevent farnesyl pyrophosphate from being converted to $\alpha$ farnesene and thus explain the correlation between scald and $\alpha$-farnesene levels. This hypothesis is readily testable.

\section{Storage conditions}

High $\mathrm{O}_{2}$ levels, low carbon dioxide levels, ethylene accumulation, and poor ventilation conditions during storage increase scald incidence and severity (Lau, 1985a, 1985b; Little and Peggie, 1987; Little et al., 1985; Manseka and Vasilakakis, 1993; Porritt, 1966; Roberts et al., 1963).

\section{ROLE OF BIOCHEMICAL FACTORS IN SCALD}

\section{Volatiles}

Early investigations by Brooks et al. (1919) and studies by Fidler (1950) suggested that volatile substances produced by the fruits were the cause of scald. Wrapping fruits with mineral oil-impregnated paper was partially successful in controlling scald, so they hypothesized that some volatile organic substance produced by the fruit was absorbed in the oil and thus prevented its accumulation in the cuticle. Many researchers believe that natural volatiles produced by apple fruits, including $\alpha$-farnesene (2,6,10-trimethyl-2,6,9,11dodecatetraene) and its oxidation products, such as conjugated trienes, conjugated trienols, and 6-methyl-5-hepten-2-one (MHO) may be involved in scald development (Du and Bramlage, 1993; Filmer and Meigh, 1971; Huelin and Coggiola, 1970a; Meigh and Filmer, 1969; Murray, 1969; Murray et al., 1964; Song and Beaudry, 1996; Spicer et al., 1993; Wang and Dilley, 1997; Watkins et al., 1993; Whitaker et al., 1997). Fidler (1950) concluded that scald development involves a volatile as well as a nonvolatile substance. $\alpha$ Farnesene was implicated in scald development more than four decades ago (Meigh, 1969). This compound accumulates in apples soon after harvest (Meigh and Filmer, 1969) and undergoes auto-oxidation by free radicals; the primary monomeric products are conjugated triene hydroperoxides (Anet, 1969) and conjugated trienols (Whitaker et al., 1997), which accumulate during subsequent storage (Anet, 1972a). The concentration and time of appearance of these oxidation products determined the severity of the disorder (Anet, 1972b). Scald development in 'Granny Smith', a cultivar very susceptible to scald, was correlated with the oxidation of $\alpha$-farnesene to conjugated triene hydroperoxides (Filmer and Meigh, 1971; Huelin and Coggiola, 1970a). Extensive investigations in Australia suggest that scald results from the auto-oxidation of $\alpha$ farnesene in the fruit skin (Anet, 1972a; Anet and Coggiola, 1974; Huelin and Coggiola, 1968, 1970b, 1970c; Huelin and Murray, 1966; Meigh and Filmer, 1969). The oxidation of $\alpha$ farnesene yields conjugated triene hydroperoxide free-radicals and conjugated trienols (Whitaker et al., 1997), which may injure the cells and give rise to the symptoms of scald (Rowan et al., 1995). Song and Beaudry (1996) found that application of 6-methyl-5-hepten2 -one (MHO), a product of $\alpha$-farnesene oxidation, applied to apple fruits caused a scald-like disorder. And, Mir et al., (1999) found that the time course of a poststorage burst of $\mathrm{MHO}$ production was associated with development of scald symptoms while DPA-treated fruits had neither such a burst in MHO nor did they develop scald. Ventilation disperses $\alpha$ farnesene and reduces scald (Anet, 1972b); however, Matich et al. (1998) suggested that the effect on scald may not be explained by loss of $\alpha$-farnesene alone, since the rate of loss from the surface of the fruit depends more on 
time of exposure during storage than on its concentration in the wax.

Collectively, research strongly supports the premise that some volatile(s) is closely related to scald development. The pathway of $\alpha$ farnesene production in apples may have important implications for scald development. Rupasinghe et al. (1998) found that $\alpha$-farnesene is derived from farnesyl pyrophosphate (FPP) and not from farnesol. The primary volatile produced during early stages of $\alpha$-farnesene oxidation is MHO (Anet, 1972a). Exogenous application of MHO vapor induced scald symptoms on nine cultivars of apple; scald-susceptible cultivars were more sensitive than scaldresistant ones (Song and Beaudry, 1996). The time course of a poststorage burst of $\mathrm{MHO}$ production was associated with development of scald symptoms, while DPA-treated fruits had neither such a burst in MHO nor did they develop scald, suggesting that MHO may be a chemical factor in scald development. MHO, which had partitioned into the epicuticular wax of fruits stored hypobarically, was released upon transfer of fruits to $20^{\circ} \mathrm{C}$; both MHO accumulation and scald development were directly proportional to the duration of the delay in transfer to hypobaric storage (Wang and Dilley, 1999a). However, cultivars that did not develop scald also showed similar MHO levels and release kinetics. Application of ILOS at $0.25 \%$ and $0.5 \% \mathrm{O}_{2}$ inhibited $\alpha$ farnesene and $\mathrm{MHO}$ production; the accumulation of MHO was highly related to scald development of apples while accumulation of $\alpha$-farnesene was not (Wang and Dilley, 1999b).

Extensive analysis of the volatiles produced by apples receiving low $\mathrm{O}_{2}$ stress or ethanol vapor treatments support the premise that metabolism of $\alpha$-farnesene in the pigment-bearing cells is closely associated with development of scald. Scald development is highly correlated with accumulation of $\mathrm{MHO}$ (Mir et al., 1999; Song and Beaudry, 1996; Wang and Dilley, 1997). Moreover, DPA inhibited production of MHO, but not of $\alpha$ farnesene from which MHO is derived. Our studies on fruits stored under continuous hypobaric ventilation (including 'Granny Smith') demonstrate that apples do not scald even after a year of such storage nor after subsequent removal to air at ambient temperature (Wang and Dilley, 1999a). Hypobaric storage favors the removal of all volatiles, including ethylene, produced by the fruits, although the fruits produce normal levels of $\alpha$-farnesene and its oxidation product $\mathrm{MHO}$ following hypobaric storage. We suspect that the fruit's capacity to convert $\alpha$-farnesene to $\mathrm{MHO}$ is prevented during hypobaric ventilation. However, hypobaric storage can control scald only if applied during the first month of storage at low temperature. This suggests that some chillingrelated and aerobic metabolism-related phenomena occur during this period that is related to scald and these processes potentiate scald development in an irreversible manner. Hypobaric ventilation after these events have been entrained has no effect on scald development. Our studies with ILOS suggest a similar scenario, and, moreover, may explain scald control by continuous ultra-low oxygen levels. The low-temperature aerobic metabolism during the first few weeks of storage, which predispose apples to scald, may involve the consequences of active oxygen species during the scald induction period.

\section{Active oxygen species and enzyme systems}

Active oxygen species (AOS) oxidize protein amino acid residues, such as lysine, resulting in formation of carbonyl groups, as measured by carbonyl content, and this is associated with scald development (Wang, 1998). All plant cells produce AOS such as $\mathrm{O}_{2}^{-}$and $\mathrm{H}_{2} \mathrm{O}_{2}$ in aerobic metabolism. These AOS are normally dissipated in the cells by enzymatic reactions and by naturally occurring antioxidants. Failure of these defense systems to keep the titer of AOS at low levels can result in AOS interacting nonenzymatically to produce more highly reactive species (Halliwell and Gutteridge, 1989), such as the hydroxyl radical $(\cdot \mathrm{OH})$, peroxyl radical $(\cdot \mathrm{OOH})$, and singlet oxygen $\left({ }^{1} \mathrm{O}_{2}\right)$. Ubiquitous enzymes, such as catalase, peroxidase, ascorbic acid peroxidase, and glutathione peroxidase, convert $\mathrm{H}_{2} \mathrm{O}_{2}$ to water. The combined action of these enzymes with naturally occurring antioxidants maintains nondamaging levels of $\cdot \mathrm{OH}$ radicals that otherwise may nondiscriminately destroy membrane-bound lipids and proteins and cytosolic enzymes essential for cellular homeostasis (Halliwell and Guttridge, 1989). In any event, the action of active oxygen species cannot be excluded from being involved at some stage of scald development.

\section{Antioxidants}

Anet (1972b) proposed that the high scald susceptibility of immature apples was due to an inefficient antioxidant system in the peel. Eleven antioxidants from apple peel were isolated by using thin-layer chromatography, but only three tocopherols were identified (Anet, 1974). He concluded that scald did not occur if the concentrations of the antioxidants remained adequate to limit $\alpha$-farnesene oxidation. Lipid-soluble antioxidant activity in apple peel at harvest was negatively correlated with scald development (Meir and Bramlage, 1988). Scalded tissue contained less $\alpha$-tocopherol than nonscalded tissue in the same fruit (Gallerani et al., 1990). Antioxidant concentrations at harvest were inversely related to maximum conjugated triene concentrations at the end of storage and to scald development. However, no individual antioxidant was associated consistently with conjugated triene accumulation or scald development. As conjugated triene concentrations increased during storage, total lipid-soluble antioxidant activity also increased, but water-soluble antioxidants generally decreased (Barden and Bramlage, 1994b). Abdallah et al. (1997) reported that wounding apples with a hypodermic needle both induced an increase in cinnamic acid derivatives with antioxidant activity and inhibited development of scald.
Several antioxidant chemicals control scald and DPA is particularly effective. Lurie et al. (1989a) concluded that DPA prevents scald by its general antioxidant effect and not specifically by preventing the oxidation of $\alpha$-farnesene; it affects other metabolic processes as well. Diphenylamine inhibits electron transport in plant mitochondria (Baker (1963). Superficial scald of 'd'Anjou' pears (Chen et al., 1990) and apples (Johnson et al., 1980) is controlled by ethoxyquin, an antioxidant commonly used to control oxidative rancidity in poultry feeds. The antioxidants BHT and BHA (Wills and Scott, 1977) also reduce scald; BHA and BHT are widely used in food packaging to prevent lipid oxidation. Phorone (2,6-dimethyl-2,5heptadien-4-one) both controls scald and limits the accumulation of $\alpha$-farnesene and its conjugated triene oxidation products in fruits during storage (Scott et al., 1980), but taints the flavor of the apples; furthermore, no toxicology data are available. Some monoterpenes are effective in controlling scald (Wills et al., 1977), and ascorbate-6-palmitate is somewhat effective (Bauchot and John, 1996).

\section{CA STORAGE TECHNOLOGY TO CONTROL SCALD}

\section{Low or ultra-low oxygen CA}

Ultra-low $\mathrm{O}_{2}$ (ULO) levels in CA storage reduce scald (Little and Peggie, 1987). Decreasing the $\mathrm{O}_{2}$ level to $\approx 0.7 \%$ during CA storage can effectively control scald of 'Delicious' apples in some growing regions and seasons, but not in others (Lau, 1990; Yearsley et al., 1996). Storage under ultra-low $\mathrm{O}_{2} \mathrm{CA}$ conditions led to markedly lower scald levels on postmature fruit, but did not greatly reduce scald on premature and mature fruit (Truter et al., 1994). CA storage at $0.7 \% \mathrm{O}_{2}$ has effectively controlled scald of 'Delicious' apples in the Northwest (Lau, 1990). For other regions, the results have been less promising and some cultivars show intolerance to the low $\mathrm{O}_{2}$ levels needed to control scald (Gran and Beaudry, 1993). Low or ultra-low $\mathrm{O}_{2}$ also showed similar results in reducing or controlling apple scald in other studies (Chen et al., 1985; Little, 1985; Patterson and Workman, 1962; Porritt, 1966; Roberts et al., 1963; Sharples and Johnson, 1981; Truter et al., 1994; Yearsley et al., 1996). Moreover, some cultivars are susceptible to low $\mathrm{O}_{2}$ injury, and do not achieve optimum dessert quality subsequent to longterm CA storage at $\mathrm{O}_{2}$ levels below $1 \%$ (Gran and Beaudry, 1993; Little, 1985; Truter et al., 1994). This may have a negative effect on consumer acceptance of apples in the United States as was found in Europe following ULO storage. Storage at $1.5 \% \mathrm{O}_{2}$ maintains flesh firmness and flavor for most of the cultivars we have examined over many years and largely controls scald, whereas long-term CA storage at higher $\mathrm{O}_{2}$ levels does not (Dilley, 1990).

\section{Low ethylene CA}

Reducing or removing ethylene in the storage atmosphere reduces scald of apples (Knee 
and Hatfield, 1981; Little et al., 1985; Liu, 1985; Skrzynski et al., 1985). Du and Bramlage (1994) suggested that ethylene played a fundamental role in scald development. Inhibition of ethylene production and action may be responsible for control of scald by controlled atmospheres and modified atmospheres created by coatings (Kader, 1986). Studies with ethylene action inhibitors suggest that some aspect of ethylene action is implicated in scald development (Gong and Tian, 1998). Combining low $\mathrm{O}_{2}$ and low ethylene during storage reduces scald (Fica, 1991; Johnson et al., 1989; Lau, 1983, 1985a, 1985b; 1989, 1990, 1993; Little, 1985).

\section{Hypobaric storage}

Hypobaric storage is a system of storing commodities while ventilating with air at less than atmospheric pressure (Dilley, 1982; Wang and Dilley, 1999a). Although refrigerated storage of apples at reduced atmospheric pressures ( 0.1 to 0.2 atmospheres) prevents scald (Dilley, 1982) it is largely an experimental storage system and not cost-competitive with current CA technologies. Storage at $2 \% \mathrm{O}_{2}$ at atmospheric pressure can delay, but not prevent, scald. At 0.1 atmosphere of air the partial pressure of $\mathrm{O}_{2}$ is $76 \mathrm{~mm}-\mathrm{Hg}$, which is equivalent to $\approx 2 \% \mathrm{O}_{2}$ at atmospheric pressure. Scald did not develop either during or after transfer to static air at 1 atmosphere for 4 months, provided apples were held in air at $1{ }^{\circ} \mathrm{C}$ and placed under hypobaric conditions within 1 month after harvest (Wang and Dilley, 1999a). If hypobaric storage was delayed for 3 months, scald development was similar to that for fruits stored in air. Hypobaric ventilation favors the removal of volatiles, including ethylene, produced by the fruit and this, together with prevention of their synthesis by low oxygen partial pressures, may explain how it prevents scald.

\section{OTHER TECHNOLOGIES TO CONTROL SCALD}

\section{Chemical control}

Partial control of scald was achieved by wrapping fruits in mineral oil-impregnated paper (Brooks et al., 1919). This labor-intensive practice was in common use until the 1960s, when the antioxidant DPA was introduced and commercially developed for postharvest quality control (Smock, 1957). In this procedure, fruits are drenched in an emulsified mixture of DPA (Hall et al., 1961). Early research with DPA as a dip treatment of fruits in bulk bins was conducted in 1963 (Dilley and Dewey, 1963). This was quickly followed by development of overhead drench treatment facilities for treating entire truckloads of apples before they were stored in CA (Dewey and Dilley, 1964); this system is still widely used today throughout the United States and Canada. In Michigan alone at least 5 million bushels $(\approx 100,000 \mathrm{t})$ of apples are treated each year with a postharvest drench treatment of DPA plus thiabendazole fungicide to control scald and decay during storage. Nationally, more than half of the apples grown are similarly treated. Diphenylamine prevents the auto-oxidation of $\alpha$-farnesene in vivo and in vitro (Anet and Coggiola, 1974) and controls scald. It also controls some $\mathrm{CO}_{2}$-induced disorders (Burmeister and Dilley, 1995) and internal browning in apple (Burmeister and Rowan, 1997). Concern about applying antioxidant chemicals to apples postharvest has been raised by environmentalists, research scientists, growers, and packers, so expanding the use of these chemicals to control other disorders must be questioned.

\section{Food-compatible antioxidant coatings}

A sucrose-fatty acid ester coating can improve the storage quality of apples (Smith and Stow, 1994), and, when used with food-compatible antioxidants, can reduce apple scald for a few months (Bauchot et al., 1995b; Little and Barrand, 1989). Bauchot et al. (1995b) concluded that the limited control of scald by ascorbyl palmitate plus a sucrose-fatty acid ester is partially related to modification of the internal atmosphere of the apple, and Dodd and Bester (1993) found that the use of ascorbyl palmitate mixed with oil markedly reduced scald . Ascorbic acid alone reduced scald incidence and severity when apples were stored in CA for 43 weeks, but the effects were not consistent when apples were stored in air (Chellew and Little, 1995). Vegetable oils reduced superficial scald, probably because of a physical effect, and this was not related to chain length of fatty acids or degree of unsaturation (Bauchot et al., 1995a, 1995b; Chellew and Little, 1995; Dodd and Bester, 1993; Little and Barrand, 1989; Scott et al., 1995b; Smith and Stow, 1994).

\section{STRATEGIES TO CONTROL SCALD}

Over the past several years, researchers have found several nonchemical treatments that reduce or control scald incidence and severity. These include heat-treatment and intermittent warming, initial ethanol vapor treatment, ILOS, ULO, and initial high carbon dioxide stress. However, most of these treatments have yet to be employed commercially for long-term CA storage.

\section{Heat-treatment}

Early studies by Hardenburg and Anderson (1965) showed that prestorage heat-treatment of apples could reduce the incidence of scald. Prestorage heat-treatments of apples for $4 \mathrm{~d}$ at $38{ }^{\circ} \mathrm{C}$ provided control of scald on 'Granny Smith' apples, but this affected the flavor by reducing the organic acid content (Lurie et al., 1990, 1991). Heat-treatment of a large number of horticultural commodities induces thermotolerance to high and low temperatures and ameliorates chilling injury (Lurie, 1998).

\section{Ethanol vapor treatment}

Recent studies (Ghahramani and Scott, 1998a; Scott et al., 1995a; Wang, 1998; Wang and Dilley, 1996; Wang et al., 1995, 1997a) indicate that ethanol vapor treatments control scald, but the mechanism of action is not known. Ethanol vapor treatment inhibits the ripening of climacteric fruits (Ritenour et al., 1997) and the senescence of oat (Avena sativa L.) leaves (Satler and Thimann, 1980) and carnation (Dianthus caryophyllus L.) flowers (Heins, 1980). The efficacy of ethanol in reducing scald may result from its effect on reducing ethylene synthesis and by noncompetively inhibiting ethylene action (Wu et al., 1992).

\section{Initial low oxygen stress}

Exposure of fruit to ILOS induces them to produce their own ethanol (Ghahramani and Scott, 1998b; Wang and Dilley, 1996, 1997, 1999b; Wang et al., 1997a), and this may explain the efficacy of ethanol vapor treatments in reducing scald even when the fruits are subsequently stored in air. The biochemical mechanisms responsible for the beneficial effects of low $\mathrm{O}_{2}$ stress on scald control and the ensuing metabolism of ethanol remain to be elucidated. Extensive analyses of the volatiles produced by apples under low $\mathrm{O}_{2}$ stress or ethanol vapor treatments support the premise that metabolism of $\alpha$-farnesene in the pigment-bearing cells is closely associated with development of scald (Dilley and Beaudry, 1998; Ghahramani and Scott, 1998b; Wang and Dilley 1996; 1997; 1999a, 1999b). Truter et al. (1994) reported that storage under ultralow $\mathrm{O}_{2}$ conditions led to markedly lower scald levels on postmature fruit, but did not greatly reduce scald on the premature and mature fruit. Storage under the ILOS + low $\mathrm{O}_{2} \mathrm{CA}$ regime, however, induced low levels of superficial scald in premature, mature, and postmature fruit (Little et al., 1982). Recent studies by Van der Merwe et al. (1997) and Wang and Dilley (1999b) indicate good control of scald by ILOS followed by CA storage $\left(1 \%\right.$ or $1.5 \% \mathrm{O}_{2}$ with $3 \% \mathrm{CO}_{2}$ at $\left.1{ }^{\circ} \mathrm{C}\right)$.

\section{Low oxygen CA}

Our laboratory studies with CA atmosphere purging at $1.5 \% \mathrm{O}_{2}$ have continued to show good control of apple scald. This has been demonstrated at the commercial level at the Michigan State Univ. Clarksville Horticulture Experiment Station (MSU CHES) CA facility since 1987 using $1.5 \% \quad \mathrm{O}_{2}$ with purging to scrub $\mathrm{CO}_{2}$ (Dilley, 1990). Numerous Michigan CA operators have verified this procedure with good results for at least 6 months of CA storage. Success using this procedure is predicated on harvesting apples at the onset of the ethylene climacteric, having the fruit under $\mathrm{CA}$ within a week after harvest and employing a hollow fiber membrane air separator such as the Permea ${ }^{\circledR}$ (Permea, Inc., St. Louis) system for $\mathrm{CO}_{2}$ scrubbing. These parameters are not always readily achieved. For CA storage beyond 6 months, fruit generally must be harvested at preclimacteric ethylene levels in order to slow ripening and maintain fruit quality. Since 1960 , our laboratory studies have 
indicated that continuous purging with low $\mathrm{O}_{2}$ atmospheres controlled scald for at least 9 months, while nonpurged storage has not. This suggests that purging may remove a fruitproduced scald-related volatile substance that would otherwise accumulate. There is much precedence for this scenario dating back to the seminal studies of Brooks et al. (1919) more than 70 years ago showing that using mineral oil-coated wraps can sometimes be effective in controlling scald. Moreover, ventilation and the use of activated carbon has also reduced scald, but not consistently.

\section{CONCLUSIONS}

For U.S.-produced apples to be available year-round for fresh and processing markets, nearly half of them stored under refrigeration must be treated with a postharvest DPA drench to control scald. Without DPA or an alternative treatment, scald could destroy the market value and utility of millions of tons of apples annually. Alternative strategies are needed to control scald of apples to avoid using any postharvest-applied chemicals. Improved fruit storage technologies should be developed and extended to provide high quality and wholesome apples for the consumer at an affordable price, while at the same time assuring the producers and handlers a sufficient profit margin to encourage them to adopt these technologies. Some recent studies suggest that this goal may be achieved in the not-too-distant future. This research has confirmed the involvement of $\alpha$-farnesene in scald development and its oxidation products $\mathrm{MHO}$, conjugated triene hydroperoxide free-radicals, and conjugated trienols. Ethylene is also a scald-related factor, based on recent studies with inhibitors of ethylene action. Many factors, including cultivar, fruit maturity, natural antioxidant levels of fruits, and storage conditions affect scald development. Postharvest-drench treatment with DPA is used commercially to control scald, but use of DPA has raised concerns of food safety and environmental problems. To control scald and ensure food safety, alternative strategies must be considered; some that have evolved include ultra-low $\mathrm{O}_{2}$ storage, ethanol vapor pretreatment, and initial low $\mathrm{O}_{2}$ stress prior to low $\mathrm{O}_{2} \mathrm{CA}$ storage. Continuous, ultralow $\mathrm{O}_{2} \mathrm{CA}$ storage can prevent apple scald, but may cause off-flavor or fruit fermentation in some cultivars or growing locations. Ethanol vapor pretreatment can attenuate scald but its effectiveness may be lost after long-term storage. Initial low $\mathrm{O}_{2}$ stress $\left(0.25 \%\right.$ to $0.5 \% \mathrm{O}_{2}$ for 2 weeks), followed by CA storage at $1.5 \% \mathrm{O}_{2}$ and $3 \% \mathrm{CO}_{2}$, can significantly control or prevent scald; this treatment strongly inhibits the conversion of $\alpha$-farnesene to its oxidation product MHO. Volatiles produced by fruits during the first month in storage appear to be important in development of scald later during storage. This conclusion is based on the observation that hypobaric storage prevents scald only if fruits are placed under hypobaric conditions within 1 month after harvest. Ethanol and ILOS treatment effects on attenuating scald may have a common basis by inhibiting the formation of $\alpha$-farnesene and its subsequent conversion to $\mathrm{MHO}$.

\section{Literature Cited}

Abdallah, A.Y., M.IGil,W. Biasi, andE.J. Mitcham. 1997. Inhibition of superficial scald in apples by wounding: Changes in lipids and phenolics. Postharvest Biol. Technol. 12:203-212.

Anet,E.F.L.J. 1969. Auto-oxidation of $\alpha$-farnesene. Austral. J. Chem. 22:2403-2410.

Anet, E.F.L.J. 1972a. Superficial scald, a functional disorder of stored apples: VIII. Volatile products from the autoxidation of $\alpha$-farnesene. J. Sci. Food Agr. 23:605-608.

Anet, E.F.L.J. 1972b. Superficial scald, a functional disorder of stored apples: IX. Effect of maturity and ventilation. J. Sci. Food Agr. 23:763-769.

Anet, E.F.L.J. 1974. Superficial scald, a functional disorder of stored apples: XI. Apple antioxidants. J. Sci. Food Agr. 25:299-304.

Anet, E.F.L.J. and I.M. Coggiola. 1974. Superficial scald, a functional disorder of stored apples: $\mathrm{X}$. Control of $\alpha$-farnesene autoxidation. J. Sci. Food Agr. 25:293-298.

Bain, J.M. 1956. A histological study of the development of superficial scald in 'Granny Smith' apples. J. Hort. Sci. 31:234-238.

Bain, J.M. and F.V. Mercer. 1963. The submicroscopic cytology of superficial scald, a physiological disease of apples. Austral. J. Biol. Sci. 16:442-449.

Baker, J.E. 1963. Diphenylamine inhibition of electron transport in plant mitochondria. Arch. Biochem. Biophys. 103:148-155.

Barden, C.L. and W.J. Bramlage. 1994a. Separating the effects of low temperature, ripening and light on loss of scald susceptibility in apples before harvest. J. Amer. Soc. Hort. Sci. 119:5458.

Barden, C.L. and W.J. Bramlage. 1994b. Relationships of antioxidants in apple peel to changes in $\alpha$-farnesene and conjugated trienes during storage, and to superficial scald development after storage. Postharvest Biol. Technol. 4:23-33.

Barden, C.L. and W.J. Bramlage. 1994c. Accumulation of antioxidants in apple peel as related to preharvest factors and superficial scald susceptibility of the fruit. J. Amer. Soc. Hort. Sci 119:264-269.

Bauchot, A.D. and P. John. 1996. Scald development and the levels of $\alpha$-farnesene and conjugated triene hydroperoxides in apple peel after treatment with sucrose ester-based coatings in combination with food-approved antioxidants. Postharvest Biol. Technol. 7:41-49.

Bauchot, A.D., P. John, Y. Soria, and I. Recasens 1995a. Carbon dioxide, oxygen, and ethylene changes in relation to the development of scald in Granny Smith apples after cold storage. J. Agr. Food Chem. 43:3007-3011.

Bauchot, A.D., P. John, Y. Soria, and I. Recasens $1995 \mathrm{~b}$. Sucrose ester-based coatings formulated with food-compatible antioxidants in the prevention of superficial scald in stored apples. J. Amer. Soc. Hort. Sci. 120:491-496.

Bauchot, A.D., S.J. Reid, G.S Ross, and D.M. Burmeister. 1999. Induction of apple scald by anaerobiosis has similar characteristics to naturally occurring superficial scald in 'Granny Smith' apple fruit. Postharvest Biol. Technol. (In press.)

Blanpied, G.D. 1990. A review of the biology of storage scald and the technology of its control. Washington State Univ. Tree Fruit Postharvest J. 1:14-16.

Bramlage, W.J., M. Drake, and J.H. Baker. 1974 Relationships of calcium content to respiration and postharvest condition of apples. J. Amer.
Soc. Hort. Sci. 99:376-378.

Brooks, C., I.S. Cooley, and D.F. Fisher. 1919 Nature and control of apple scald. J. Agr. Res. 18:211-240.

Burmeister, D.M. and D.R. Dilley. 1995. A 'scaldlike' controlled atmosphere storage disorder of Empire apples-A chilling injury induced by $\mathrm{CO}_{2}$. Postharvest Biol. Technol. 6:1-7.

Burmeister, D.M. and S. Rowan. 1997. Physiological and biochemical basis for the Braeburn browning disorder (BBD). In: E.J. Mitchman (ed.). Apples and pears. Proc. $7^{\text {th }}$ Intl. Controlled Atmosphere Res. Conf. 2:126-131.

Chellew, J.P. and C.R. Little 1995. Alternative methods of scald control in 'Granny Smith' apples. J. Hort. Sci. 70:109-115.

Chen, P.M., K.L. Olsen, and M. Meheriuk. 1985. Effect of low-oxygen atmosphere on storage scald and quality preservation of 'Delicious' apples. J. Amer. Soc. Hort. Sci. 110:16-20.

Chen, P.M., D.M. Varga, E.A. Mielke, T.J. Facteau, and S.R. Drake. 1990. Control of superficial scald on 'd'Anjou' pears by ethoxyquin: Oxidation of $\alpha$-farnesene and its inhibition. J. Food Sci. 55:171-174.

Christopher, E.P. 1941. Influence of time of harvest on storage scald development of Rhode Island Greening and Cortland apples. Proc. Amer. Soc. Hort. Sci. 39:58. (Abstract.)

Couey, H.M. and M.W. Williams. 1973. Preharvest application of ethephon on scald and quality of stored 'Delicious' apples. HortScience 8:5657.

Crawford, R.M.M. and R. Braendle. 1996. Oxygen deprivation stress in a changing environment. J. Expt. Bot. 47:145-159.

Curry, E.A. 1994. Preharvest applications of ethephon reduce superficial scald of 'Fuji' and 'Granny Smith' apples in storage. J. Hort. Sci. 69:11111116

Dewey, D.H. and D.R. Dilley. 1964. Control of storage scald. Michigan State Univ. Ext. Bul. 470.

Dilley, D.R. 1982. Principles and effects of hypobaric storage of fruits and vegetables. Amer. Soc. Heating, Refrigeration and Air Conditioning Eng. Trans. 88:1461-1478.

Dilley, D.R. 1990. Application of air separator technology for the control of superficial scald of apples not treated with scald inhibiting chemicals, p. 656. In: Proc. 23rd Intl. Hort. Congr., Florence, Italy, 27 Aug.-1 Sept. 1990.

Dilley, D.R. and R.M. Beaudry. 1998. NE-103 Postharvest physiology of fruits. Annu. Rpt. Michigan Agr. Expt. Sta., East Lansing.

Dilley, D.R., R.R. Dedolph, D.C. MacLean, and D.H. Dewey. 1963. Apple scald induction by anaerobiosis. Nature 200:1229-1230.

Dilley, D.R., and D.H. Dewey. 1963. Dip treatment of apples in bulk boxes with diphenylamine for control of storage scald. Michigan Agr. Expt. Sta. Quart. Bul. 46:73-79.

Dodd, M.C. and R. Bester. 1993. Alternative antioxidants for control of superficial scald. Washington State Univ. Tree Fruit Postharvest J. 4:33-34.

Du, Z. and W.J. Bramlage. 1993. A modified hypothesis on the role of conjugated trienes in superficial scald development on stored apples. J. Amer. Soc. Hort. Sci. 118:807-813.

Du, Z. and W.J. Bramlage. 1994. Roles of ethylene in the development of superficial scald in 'Cortland' apples. J. Amer. Soc. Hort. Sci. 119:516-523.

Ella, K.M., K.E. Meier, A. Kumar, Y. Zhang, and G.P. Meier. 1997. Utilization of alcohols by plant and mammalian phospholipase D. Biochem. Mol. Biol. Intl. 41:715-724.

Emongor, V.E., D.P. Murr, and E.C. Lougheed. 
1994. Preharvest factors that predispose apples to superficial scald. Postharvest Biol. Technol. 4:289-300.

Fica, J. 1991. The response of Cortland apples to low oxygen and low ethylene CA storage. Fruit Sci. Ret. 18:63-67.

Fidler, J.C. 1950. Studies of the physiologically active volatile organic compounds produced by fruits: The rate of production of carbon dioxide and volatile organic compounds by King Edward VII apples in gas storage, and the effect of the removal of the volatiles from the atmosphere of the store in the incidence of superficial scald. J. Hort. Sci. 25:81-110.

Fidler, J.C. 1957. Scald and weather. Food Sci. Abstr. 28:545-554.

Filmer, A.A.E. and D.F. Meigh. 1971. Natural skin coating of the apple and its influence on scald in storage. IV. Oxidation products of $\alpha$-farnesene. J. Sci. Food Agr. 22:188-190.

Gallerani, G., G.C. Pratella, and R. A. Budini. 1990. The distribution and role of natural antioxidant substances in apple fruit affected by superficial scald. Adv. Hort. Sci. 4:144-146.

Ghahramani, F. and K.J. Scott. 1998a. The action of ethanol in controlling superficial scald of apples. Austral. J. Agr. Res. 49:199-205.

Ghahramani, F. and K.J. Scott. 1998b. Oxygen stress of Granny Smith apples in relation to superficial scald, ethanol, $\alpha$-farnesene and conjugated trienes. Austral. J. Agr. Res. 49:207210.

Gong, Y. and M.S. Tian. 1998. Inhibitory effect of diazocyclopentadienes on the development of superficial scald in Granny Smith apple. Plant Growth Regul. 26:117-121.

Gran, C.D. and R.M. Beaudry. 1993. Determination of the low oxygen limit for several commercial apple cultivars by respiratory quotient breakpoint. Postharvest Biol. Technol. 3:259267.

Greene, D.W., W.J. Lord, and W.J. Bramlage. 1977. Mid-summer applications of ethephon and daminozide on apples. II. Effects on 'Delicious'. J. Amer. Soc. Hort. Sci. 102:494-497.

Hall, E.G., K.J. Scott, and G.G. Coote. 1961. Control of superficial scald on Granny Smith apples with diphenylamine. Austral. J. Agr. Res. 12:834-853.

Halliwell, B. and I.C. Gutteridge. 1989. Free radicals in biology and medicine. Clarendon Press, Oxford, U.K.

Hammett, L.K. 1976. Ethephon influence on storage quality of 'Starkrimson Delicious' and 'Golden Delicious' apples. HortScience 11:5759.

Hardenburg, R.E. and R.E. Anderson. 1965. Postharvest chemical, hot water, and packaging treatments to control apple scald. Proc. Amer. Soc. Hort. Sci. 87:93-99.

Heins, R.D. 1980. Inhibition of ethylene synthesis and senescence in carnation by ethanol. J. Amer. Soc. Hort. Sci. 105:141-144.

Heller, M. 1978. Phospholipase D, p. 267-326. In: R. Paoletti and D. Kritchevsky (eds.). Adv. in Lipid Research, Vol. 16. Academic Press, New York.

Huelin, F.E. and I.M. Coggiola. 1968. Superficial scald, a functional disorder of stored apples: IV. Effect of variety, maturity, oiled wraps and diphenylamine on the concentration of $\alpha$ farnesene in the fruit. J. Sci. Food Agr. 19:297301.

Huelin, F.E. and I.M. Coggiola. 1970a. Superficial scald, a functional disorder of stored apples: V. Oxidation of $\alpha$-farnesene and its inhibition by diphenylamine. J. Sci. Food. Agr. 21:44-48.

Huelin, F.E. and I.M. Coggiola. 1970b. Superficial scald, a functional disorder of stored apples. VI.Evaporation of $\alpha$-farnesene from the fruit. J. Sci. Food Agr. 21:82-86

Huelin, F.E. and I.M. Coggiola. 1970c. Superficial scald, a functional disorder of stored apples. VII.-Effect of applied $\alpha$-farnesene, temperature and diphenylamine on scald and the concentration and oxidation of $\alpha$-farnesene in the fruit. J. Sci. Food Agr. 21:584-589.

Huelin, F.E. and K.E. Murray. 1966. $\alpha$-Farnesene in the natural coating of apples. Nature 210:12601261.

Ingle, M. and M. D’Souza. 1989. Physiology and control of superficial scald of apples: A review. HortScience 24:28-31.

Johnson, D.S., J.G. Allen, and T.M. Warman. 1980. Postharvest application of diphenylamine and ethoxyquin for the control of superficial scald on 'Bramley's Seedling' apples. J. Sci. Food Agr. 31:1189-1194.

Johnson, D.S., J. Prinja, and S.M. Smith. 1989. The use of controlled atmosphere (CA) conditions for the control of bitter pit and superficial scald in Bramley's Seedling apples. Proc. 5th Intl. Controlled Atmosphere Res. Conf. 1:157-168.

Kader, A.A. 1986. Biological and physiological basis for effects of controlled and modified atmosphere on fruits and vegetables. Food Technol. 40:99-103.

Knee, M. and S.G.S. Hatfield. 1981. Benefits of ethylene removal during apple storage. Ann. Appl. Biol. 98:157-165.

Lau, O.L. 1983. Effects of storage procedures and low oxygen and high carbon dioxide atmospheres and storage quality of 'Spartan' apples. J. Amer. Soc. Hort. Sci. 108:953-957.

Lau, O.L. 1985a. Storage procedures, low oxygen and low carbon dioxide atmospheres on storage quality of 'Golden Delicious' and 'Delicious' apples. J. Amer. Soc. Hort. Sci. 110:541-547.

Lau, O.L. 1985b. Storage responses of four apple cultivars to low oxygen atmosphere. Proc. 4th Natl. Controlled Atmosphere Res. Conf. 126:4356.

Lau, O.L. 1989. Control of storage scald in 'Delicious' apples by diphenylamine, low oxygen atmosphere and ethylene scrubbing. Proc. 5th Intl. Controlled Atmosphere Res. Conference 1:177-184.

Lau, O.L. 1990. Efficacy of diphenylamine, ultralow oxygen, and ethylene scrubbing on scald control in 'Delicious' apples. J. Amer. Soc. Hort. Sci. 115:959-961.

Lau, O.L. 1993. Scald and its control: The North American situation. Acta Hort. 326:225-230.

Little, C.R. 1985. The advantages of ultra low oxygen storage, p. 80-90. In: P.J. Sharkey (ed.). Proc. Postharvest Hort. Workshop, Melbourne, Australia. CSIRO, Sydney, Australia.

Little, C.R. and L. Barrand. 1989. Seasonal orchard and storage conditions affecting storage scald in pome fruit. Proc. 5th Intl. Controlled Atmosphere Res. Conf., Idaho, USA, p. 177-184.

Little, C.R., J.D. Faragher, and H.S. Taylor. 1982. Effects of initial low oxygen stress treatments in low oxygen modified atmosphere storage of Granny Smith apples. J. Amer. Soc. Hort. Sci. 107:320-323.

Little, C.R. and I.A. Peggie. 1987. Storage injury of pome fruits caused by stress levels of $\mathrm{O}_{2}, \mathrm{CO}_{2}$, temperature and ethylene. HortScience 22:783790.

Little, C.R. H.J. Taylor, and F. McFarlane. 1985. Postharvest and storage factors affecting superficial scald and core flush of Granny Smith apples. HortScience 20:1080-1082.

Liu, F.W. 1985. Conditions for low ethylene CA storage of apples: A review. Proc. 4th Natl.
Controlled Atmosphere Res. Conf., North Carolina State Univ. Hort. Rept. 126:127-134.

Lurie, S. 1998. Postharvest heat treatments. Postharvest Biol. Technol. 14:257-269.

Lurie, S., J. Klein, and R. Ben-Arie. 1989a. Physiological changes in diphenylamine-treated 'Granny Smith' apples. Israel J. Bot. 38:199207.

Lurie, S., J.D. Klein, and R. Ben-Arie. 1990. Postharvest heat treatment as a possible means of reducing superficial scald of apples. J. Hort. Sci. 65:503-509.

Lurie, S., J.D. Klein, and R. Ben-Arie. 1991. Prestorage heat treatment delays development of superficial scald on 'Granny Smith' apples. HortScience 26:166-167.

Lurie, S., S. Meir, and R. Ben-Arie. 1989b. Preharvest ethephon sprays reduce superficial scald of 'Granny Smith' apples. HortScience 24:104106.

Manseka, V.S. and M. Vasilakakis. 1993. Effect of storage maturity, postharvest treatments and storage conditions on superficial scald and quality of apples. Acta Hort. 326:213-224.

Matich, A.J., N.H. Banks, and D.D. Rowan. 1998 Modification of $\alpha$-farnesene levels in coolstored 'Granny Smith' apples by ventilation. Postharvest Biol. Technol. 14:159-170.

Meigh, D.F. 1969. Production of $\alpha$-farnesene and incidence of scald in stored apples. Qual. Plant. Materials Veg. 19:243-254.

Meigh, D.F. 1970. Apple scald, p. 555-569. In: A.C. Hulme (ed.). The biochemistry of fruits and their products. Vol. 1. Academic Press, London.

Meigh, D.F. and A.E. Filmer. 1969. The natural skin coating of the apple and its influence on scald in storage: III. $\alpha$-Farnesene. J. Sci. Food Agr. 20:139-143.

Meir, S. and W.J. Bramlage. 1988. Antioxidant activity in 'Cortland' apple peel and susceptibility to superficial scald after storage. J. Amer. Soc. Hort. Sci. 113:412-418.

Melville, F. and S.E. Hardisty. 1953. Scald in Granny Smith apples. Practical aspects of control. J. Agr. W. Austral. 2:101-107.

Mir, N., R. Perez, and R.M Beaudry. 1999. A poststorage burst of 6-methyl-5-hepten-2-one (MHO) may be related to superficial scald development in 'Cortland' apples. J. Amer. Soc. Hort. Sci. 124:173-176.

Murray, K.E. $1969 . \quad \alpha$-Farnesene: Isolation from the natural coating of apples. Austral. J. Chem. 22:197-204.

Murray, K.E., F.E. Huelin, and J.B. Davenport. 1964. Occurrence of $\alpha$-farnesene in the natural coating of apples. Nature 204:80.

Patterson, M.E. and M. Workman. 1962. The influence of oxygen and carbon dioxide on the development of apple scald. Proc. Amer. Soc. Hort. Sci. 80:130-136.

Porritt, S.W. 1966. The effect of low oxygen and low concentrations of carbon dioxide on the quality of apples stored in controlled atmospheres. Can. J. Plant Sci. 46:317-321.

Ritchie, S. and S. Gilroy. 1998. Abscisic acid signal transduction in the barley aleurone is mediated by phospholipase D activity. Proc. Natl. Acad. Sci. USA 95:2697-2702.

Ritenour, M.A., M.E. Mangrich, J.C. Beaulieu, A. Rab, and M.E. Saltveit. 1997. Ethanol effects on the ripening of climacteric fruit. Postharvest Biol. Technol. 12:35-42.

Roberts, E.A., E.G. Hall, and K.J. Scott. 1963. The effect of carbon dioxide and oxygen concentration on superficial scald on Granny Smith apples. Austral. J. Agr. Res. 14:765-777.

Rowan, D.D., J.M. Allen, S. Fielder, J.A. Spicer, and M.A. Brimble. 1995. Identification of con- 
jugated triene oxidation products of $\alpha$-farnesene in apple skin. J. Agr. Food Chem. 43:2040 2045.

Rupasinghe, H.P.V., G. Paliyath, and D.P. Murr. 1998. Biosynthesis of $\alpha$-farnesene and its relation to superficial scald development in 'Delicious' apples. J. Amer. Soc. Hort. Sci. 123:882886.

Satler, S.O. and K.V. Thimman. 1980. The influence of aliphatic alcohols on leaf senescence. Plant Physiol. 66:395-399.

Saltveit, M.E. 1994. Exposure to alcohol vapours reduces chilling-induced injury of excised cucumber cotyledons, but not of seedlings or excised hypocotyl segments. J. Expt. Bot. 45:813821.

Scott, K.J., R.B.H. Wills, and McBailey, W. 1980. The action of phorone and other compounds in controlling superficial scald of apples. Scientia Hort. 13:9-14.

Scott, K.J., C.M.C. Yuen, and F. Grahramani. 1995a. Ethanol vapor-A new anti-scald treatment for apples. Postharvest Biol. Technol. 6:201-208.

Scott, K.J., C.M.C. Yuen, and G.H. Kim. 1995b. Reduction of superficial scald of apples with vegetable oils. Postharvest Biol. Technol. 6:219 223.

Sharples, R.O. and D.S. Johnson. 1981. Storage of Cox in ultra low oxygen-Sensitivity to low temperature injury. Annu. Rpt. E. Malling Res. Sta. p. 133.

Shutak, V. and E.P. Christopher. 1960. Role of the cuticle in development of storage scald on Cortland apples. Proc. Amer. Soc. Hort. Sci. 76:106-111.

Skrzynski, J., J. Fica, and D.R. Dilley. 1985. The effect of ethylene removal during controlled atmosphere storage of Red Delicious, Empire, Jonathan, Idared, and Law Rome apples. Proc. 4th Natl. Controlled Atmosphere Res. Conf. North Carolina State Univ. Hort. Rept. 126:115126.

Smith, S.M. and J.R. Stow. 1994. The potential of a sucrose ester coating material for improving the storage and shelf-life qualities of Cox's Orange Pippin apples. Ann. Appl. Biol. 104:383-391.

Smock, R.M. 1957. A comparison of treatments for control of the apple scald disease. Proc. Amer. Soc. Hort. Sci. 69:91-100.
Smock, R.M. 1961. Methods of scald control on the apple. Cornell Univ. Agr. Expt. Sta. Bul. No. 970.

Song, J. and R.M. Beaudry. 1996. Rethinking apple scald: New hypothesis on the causal reason for development of scald in apples. HortScience 31:605.

Spicer, J.A., M.A. Brimble, and D.D. Rowan. 1993. Oxidation of $\alpha$-farnesene. Austral. J. Chem. 46:1929-1939.

Truter, A.B., J.C. Combrink, and S.A. Burger. 1994. Control of superficial scald in 'Granny Smith' apples by ultra-low and stress levels of oxygen as an alternative to diphenylamine. J. Hort. Sci. 69:581-587.

Van der Merwe, J.A., J.C. Combrink, A.B. Truter, and F.J. Calitz. 1997. Effect of initial low oxygen stress treatment and CA storage at increased carbon dioxide levels on post-storage quality of South African-grown 'Granny Smith' and 'Topred' apples. Proc. $7^{\text {th }}$ Intl. Controlled Atmosphere Res. Conf. 2:79-84.

Wang, Z. 1998. Alternative strategies to contro scald of apples and some biochemical bases. PhDDiss., Dept. of Horticulture, Michigan State Univ., E. Lansing.

Wang, Z. and D.R. Dilley. 1996. Ethanol vapor treatment: A new alternative approach to control superficial scald of apples. Proc. Michigan State Hort. Soc. 126:35-40.

Wang, Z. and D.R. Dilley. 1997. The relationship of $\alpha$-farnesene production and its oxidation product 6-methyl-5-hepten-2-one to superficial scald of Granny Smith, Law Rome, Red Delicious and Idared apples during controlled atmosphere and air storage. Proc. $7^{\text {th }}$ Intl. Controlled Atmosphere Res. Conf. 2:98-104.

Wang, Z. and D.R. Dilley. 1999a. Hypobaric storage reveals the nature of low temperature induction of superficial scald of apples. Postharvest Biol. Technol. (In press.)

Wang,Z. and D.R. Dilley. 1999b. Initial low oxygen stress controls superficial scald of apples. Postharvest Biol. Technol. (In press.)

Wang, Z., M. Kosittrakun, and D.R. Dilley. 1995. Developments to control the Empire 'scaldlike' disorder and superficial scald of apples. Proc. Michigan State Hort. Soc. 125:220-221.

Wang, Z., T.J. McCully, and D.R. Dilley. 1997a.
The effect of ultra low oxygen storage, initial oxygen stress and ethanol vapor treatments on controlling superficial scald of Granny Smith, Law Rome, Red Delicious and Idared apples. Proc. $7^{\text {th }}$ Intl. Controlled Atmosphere Res. Conf. 2:105-111.

Watkins, C.B., C.L. Barden, and W.J. Bramlage. 1993. Relationships among $\alpha$-farnesene, conjugated trienes and ethylene production with superficial scald development of apples. Acta Hort. 343:155-160.

Watkins, C.B. and W.J. Bramlage. 1994. Influences of preharvest temperature and harvest maturity on susceptibility of New Zealand and North American apples to superficial scald. New Zealand J. Crop and Hort. Sci. 22:69-79.

Watkins, C.B., W. J. Bramlage, and B.A. Cregoe. 1995. Superficial scald of Granny Smith apples is expressed as a typical chilling injury. J. Amer. Soc. Hort. Sci. 120:88-94.

Weeks, W.D., F. W. Southwick, M. Drake, and J.E. Steckel. 1958. The effect of varying rates of nitrogen and potassium on the mineral composition of 'McIntosh' foliage and fruit color. Proc. Amer. Soc. Hort. Sci. 71:11-19.

Whitaker, B.D., T. Solomos, and D.J. Harrison. 1997. Quantification of $\alpha$-farnesene and its conjugated trienol oxidation products from apple peel by $\mathrm{C}_{18}$ - HPLC with UV detection. J. Agr. Food Chem. 45:760-765.

Wills, R.B.H. and K.J. Scott. 1977. Evaluation of the use of butylated hydroxytoluene to reduce superficial scald of apples. Scientia Hort. 6:125127.

Wills, R.B.H., K.J. Scott, and W. McBailey. 1977. Reduction of superficial scald in apples with monoterpenes. Austral. J. Agr. Res. 28:445448.

Windus, N.D. and V.G. Shutak. 1977. Effect of ethephon, diphenylamine and daminozide on the incidence of scald development on 'Cortland' apples. J. Amer. Soc. Hort. Sci. 102:715-718.

Wu, M.J., L. Zacarias, M.E. Saltveit, and M.S. Reid. 1992. Alcohols and carnation senescence. HortScience 27:136-138.

Yearsley, C.W., N.H. Banks, S. Ganesh, and D.J. Cleland. 1996. Determination of lower oxygen limits for apple fruit. Postharvest Biol. Technol. 8:95-109. 